\section{SOI: $1.1 /$ TAS $\quad$ DOI: $10.15863 /$ TAS International Scientific Journal Theoretical \& Applied Science}

p-ISSN: 2308-4944 (print) e-ISSN: 2409-0085 (online)

Year: 2018 Issue: 09 Volume: 65

Published: $12.09 .2018 \quad \underline{\text { http://T-Science.org }}$

SECTION 1. Theoretical research in mathematics.

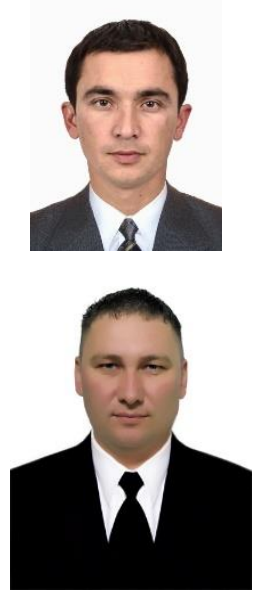

Farkhod Musajonovich Nishonov Academic Lyceum of the Fergana Polytechnic Institute, Uzbekistan

Konstantin Ivanivich Kurpayanidi Doctor of Philosophy in Economics, Professor of the Russian Academy of Natural Sciences, Corresponding Member of the International Academy of Theoretical and Applied Sciences Fergana Polytechnic Institute, Uzbekistan

ORCID:0000-0001-8354-1512 w7777@mail.ru

\title{
SOME QUESTIONS OF DESIGN OF TASKS IN MATHEMATICS
}

Abstract: In the article about the essential features of the system of problems given a definition to the system of problems; the directions of designing systems of problems in mathematics are considered.

Key words: Mathematics, the problem, the construction of mathematical problems, the methods of constructing mathematical problems.

Language: English

Citation: Nishonov FM, Kurpayanidi KI (2018) SOME QUESTIONS OF DESIGN OF TASKS IN MATHEMATICS. ISJ Theoretical \& Applied Science, 09 (65): 41-44.

Soi: http://s-o-i.org/1.1/TAS-09-65-7 Doi: crossef https://dx.doi.org/10.15863/TAS.2018.09.65.7

\section{Introduction}

In the information society, mathematical education is an important factor in the adaptation of the individual to the existing realities. Analysis of global trends in the development of education attests changes in its content, methods and organizational forms in connection with the wide use of information educational technologies. Thus, the development of these technologies is much faster than the pedagogical development of their usage in the educational process.

Thereby, overall comprehensive development of pupilsat schools and academic lyceums, the formation of their personalities and the professional success are impossible without a substantial reliance on a high level of mathematical preparation. The most important educational activity, which allows schoolchildren to learn mathematical theory, develop their creativity and independence of thinking, is problem solution. In our conviction, math problems are the main means of forming knowledge, skills and abilities of students, the development of schoolchildren by organizing educational activities. Subsequently, the efficiency of teaching and educational process depend on the choice of tasks, the methods of organizing student activities to solve them, i.e. the methodology for problem solution.

Considering the essential characteristics of the concept "task", the essential features of the concept "system of tasks" are highlighted; the essence of methods and techniques for constructing systems of problems in mathematics are revealed.

We proceed from the assumption that the theoretical foundations of designing systems of problems in mathematics are the concepts "task" and "system of tasks", requirements to the system of problems and design rules that provide these requirements, mechanisms for constructing task systems.The multidimensionality of the concept "task" is revealed through the analysis of the phenomenon from the point of view of psychological, didactic and systemic approaches.

\section{Materials and Methods}

The psychological approach emphasizes the objective nature of the problem; considers it from the point of view of the components of the activity in which the method of activity is to be found - the achievement of a certain result under certain conditions; defines the problem as a subjective education that relates to the decision maker, when the problem is decided by the decider, the goal is realized and there is a desire to solve it.

In the didactic approach, the task is considered as a form of the embodiment of the teaching material and a learning tool.

The system approach allowed to distinguish invariant characteristics of the concept provided in 
the definition: the problem - system "solver - a system of tasks", the second component which has at least one discrepancy (for example, between a condition and a requirement) in its structure, and for determination of which the solver's actions are directed after recognition and acceptance of this system.

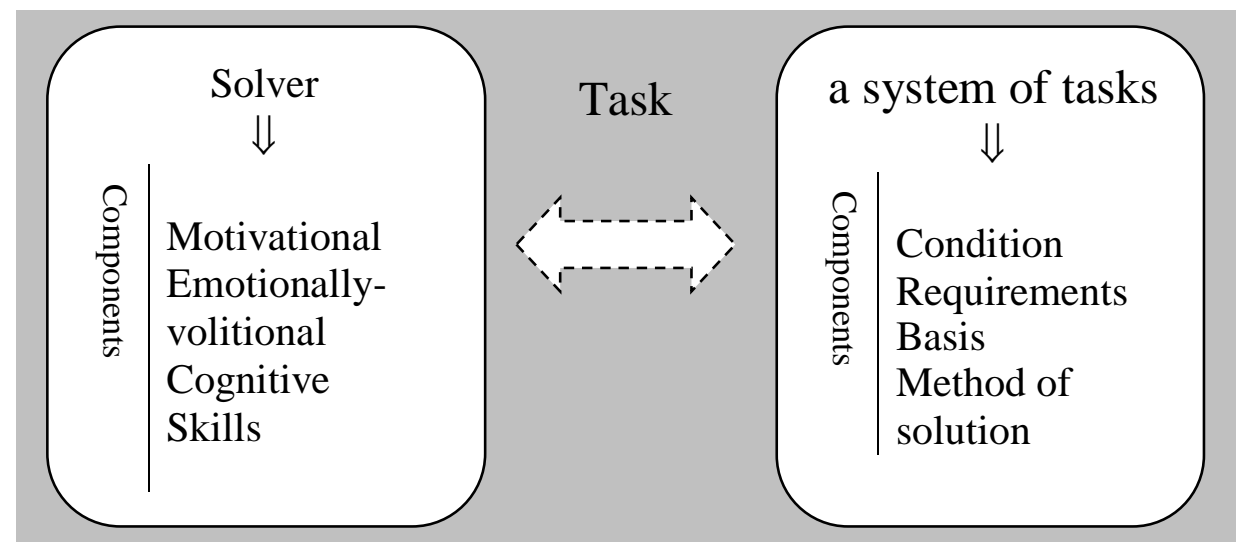

Fig.1.Static structure of the problem.

In interaction of the solver and the target system, both the system (the transformation of conditions, the change in the connection between objects, etc.) and the subject (the appropriation of knowledge, skills, experience) are subject to change.

Changes in the task system are dictated by a certain goal - didactic (for understanding the condition of the problem, mastering the way of solving, understanding the concept, etc.), developing (for development of critical thinking, development of analytical and synthetic skills, etc.), educational (for the development of interest in the subject, the formation of collectivistic qualities of the individual, etc.), controlling (for checking the completeness of knowledge, the formation of skills, etc.), organizing (for the organization of collective, pair work, providing the differentiation of education, etc.), and in certain cases lead to the emergence of the system of tasks.

To distinguish the essence of the concept of "system of problems", the task loops (G.V. Dorofeev)[1], chains (D.Poya) [2], blocks (E.V. Sukhorukova, S.V. Arutyukin, A.P. Karp) [3], crosscutting problems (N.Y. Vilenkin, A. Satvoldiev)[4], developing (M.S. Nikolsky)[5], multi-step (M.I. Zaikin)[6], multi-stage (M. Klyakly)[7], open (H. Merlin, A.V. Merlin)[8], compact problems (T.V. Ignatieva)[9] have been taken into consideration.

On the basis of highlighting the essential features of the system of tasks (the presence of a specific goal, ensuring the expected result, selectivity and ordering of the elements) given a definition: a system of tasks is a set of tasks ordered and matched in accordance with the goal acting as one whole, the interconnection and interaction of which lead to the intended result.
The result of the analysis of the works of A.G. Ball [10], V.V. Guzeeva [11], F.M. Yunusova, G.A. Kovaleyova, T.Yu. Dumina [12], etc. became the allocation of requirements to the system of tasks:

1) to the structure of the system (hierarchy, rationality of volume, increasing complexity);

2) to the functioning of the system as a whole (target sufficiency, completeness, adequacy of the content of education);

3) to tasks as elements of the system (the purpose of each task in the system of tasks, the possibility of implementing an individual approach).

The fulfillment of the requirements of the system of tasks ensures the rules of constructing: the rule of accessibility (correspondence to the level of training, the consideration of the psychological characteristics of age groups), the rule of uniformity (selection or compilation of similar tasks in accordance with the regularity of the appearance of incorrect associations, identified by the psychologist P.A. Shevarev)[13], the rule of diversity (the inclusion of tasks that are diverse in form, content and method of solution), the rule of opposition (inclusion of tasks in similar and reciprocal concepts, tasks that do not have solutions or counterexamples), the rule of goal consideration (selection of tasks in accordance with the purpose of using the system, with the special purpose of every tasks in the system) the rule of completeness (compliance with the system of knowledge, skills and abilities, the study of which is provided), the rule of complication (the location of tasks in the system), the rule of structuralism (mutual subordination), the rule of individualization (taking into account the individual characteristics of students).

The result of the analysis of various constructions of problem systems was the 
systematization of knowledge about the methods of construction. Comprehending the method of constructing the system of problems ordered in accordance with the goal of the tasks in aggregate which provides the last system characteristics; the following methods for constructing the systems of learning tasks are outlined: the method of varying the problem, the method of key problems, the target task method, the "snowball" method.

The essence of the method of varying the problem is that each problem of the system is obtained from this task by varying its content or form.

The content of a task is understood as the totality of its components: condition, requirement, basis and method of solution. Variation, specifically, is interpreted very widely. This is not only a change, but also replacement of objects and (or) relations, addition and (or) withdrawal of components (conditions, requirements).

As a result of varying, conditions may turn out as non-standardized (indeterminate, variational, overdetermined, contradictory, provocative) tasks as opposed to standardized, or definite ones, containing in condition a necessary and sufficient amount of data to obtain the only possible answer.

Problems with an unformed requirement are examples of variation of requirement.

Variation of the basis and method of solution, as a consequence, leads to the solution of one problem using different methods.

The next method is to compile a system of problems built on the principle that "each task of the system uses the result of the solution (statement or method) of the key problem" - the method of the key task. There are two points of view on the concept of a key problem - task-fact and task-method. While studying any topic of the school course, pupils can select a certain minimum of key tasks, by assimilating their solutions schoolchildren will be able to solve any task at the level of program requirements of a particular learning topic[14].

The method of the target task involves the allocation of a quite complex problem, the solution of which is divided into a number of simple ones. The division of the target task into elementary ones is carried out on the basis of analysis which leads to the students' comprehension of the idea of a solution or proof.

The "snowball" method means to use the results of the solution of previous problem while solving each problem of the system. Since the result of the solution of the problem can be both a proven fact about the object and the method implemented in the solved problem, we distinguish two versions of the "snowball": the use of the proved statement and the repetition of the operations undertaken in the previous problem.

\section{Conclusion}

In conclusion, main methods of constructing systems of tasks - the reception of reciprocal and opposite tasks, the reception of generalization and concretization, the reception of analogy - have been highlighted.

\section{References:}

1. Dorofeyev G. V. (1983) O sostavlenii tsiklov vzaimosvyazannykh zadach //Matematika v shkole. - 1983. - №. 6. - p. 34-39.

2. Poya D. (1976) Matematicheskoye otkrytiye. M.: Nauka, 1976.

3. Sukhorukova M. V., et al. (2000) Opyt sozdaniya obrazovatel'nogo servera" Optika" //Fizicheskoye obrazovaniye v vuzakh. - 2000. - T. 6. - №. 1. - p. 97-102.

4. Vilenkin N. YA., Satvoldiyev A. (1989) Metod skvoznykh zadach $\mathrm{V}$ shkol'nom kurse matematiki //Povysheniye effektivnosti obucheniya matematike v shkole.-M.: Prosveshcheniye. - 1989. - p. 101-112.

5. Nikol'skiy M. S. (1970) Ideal'no nablyudayemyye sistemy //Doklady Akademii nauk. - Rossiyskaya akademiya nauk, 1970. T. 191. - №. 6. - p. 1224-1227.

6. Zaykin M. I., Yegulemova N. N., Abramova O. M. (2014) Serii, variatsii i okrestnosti matematicheskikh zadach: Monografiya //Arzamas: Arzamasskiy filial NNGU. - 2014.

7. Klyaklya M. (2003) Formirovaniye tvorcheskoy matematicheskoy deyatel'nosti uchashchikhsya klassov s uglublennym izucheniyem matematiki v shkolakh Pol'shi //dis. d-ra ped. nauk. - 2003.

8. Merlin A. V., Merlina N. I. (1998) Nestandartnyye zadachi po matematike $\mathrm{V}$ shkol'nom kurse //Cheboksary: Klio. - 1998.

9. Ignat'yeva T. V. (2009) Konstruirovaniye zadach-kompaktov prikladnoy napravlennosti i ikh ispol'zovaniye $\mathrm{v}$ kachestve sredstva 
\begin{tabular}{l|lr|ll|ll} 
& ISRA (India) & $=\mathbf{1 . 3 4 4}$ & SIS (USA) & $=\mathbf{0 . 9 1 2}$ & ICV (Poland) & $=\mathbf{6 . 6 3 0}$ \\
Impact Factor: & ISI (Dubai, UAE) $=\mathbf{0 . 8 2 9}$ & PUHL (Russia) $=\mathbf{0 . 1 5 6}$ & PIF (India) & $=\mathbf{1 . 9 4 0}$ \\
& GIF (Australia) & $=\mathbf{0 . 5 6 4}$ & ESJI (KZ) & $=4.102$ & IBI (India) & $=\mathbf{4 . 2 6 0}$ \\
& JIF & $=\mathbf{1 . 5 0 0}$ & SJIF (Morocco) $=\mathbf{2 . 0 3 1}$ & & \\
\hline
\end{tabular}

sovershenstvovaniya obucheniya matematike v tekhnicheskikh vuzakh //N. Novgorod. - 2009.

10. Ball G. A., Volynets A. G. (2000) K analizu ideynykh osnov gumanisticheski oriyentirovannogo obrazovaniya //Gumanizatsiya obrazovaniya. - 2000. - T. 1. p. 22-51.

11. Guzeyev V. V. (1988) O novykh formakh organizatsii obucheniya //Matematika v shkole. - 1988. - №. 4. - p. 47-49.

12. Kovaleva G. I., Astakhova N. A., Dyumina T. YU. (2008) Teoriya i metodika obucheniya matematike: konstruirovaniye sistem zadach //Volgograd: Izd-vo VGPU «Peremena. - 2008.

13. Shevarev P. A. (1959) Obobshchennyye assotsiatsii v uchebnoy rabote shkol'nika. - Izdvo APN RSFSR, 1959.

14. Davydov V. V. (1972) Vidy obobshcheniya V obuchenii. - Pedagogika, 1972. 